\title{
The Effect of a Hemostatic Agent (FastAct) to Wound and Tissue Repair in a Rat Model
}

\author{
Bir Hemostatik Ajanin (Fastact) Deneysel Rat Modelinde Yara ve Doku İyileşmesi Üzerine Etkisi
}

\author{
Kemal Murat OKÇU, Necdet DOĞAN, Metin ŞENÇIMEN, Cem KORKMAZ, ${ }^{1}$ \\ Hasan Ayberk ALTUĞ, ${ }^{2}$ Tayfun İDE, ${ }^{3}$ Mesut AKYOL, ${ }^{4}$ \\ Departments of Oral and Maxillofacial Surgery Anatomy, ${ }^{1}$ Histology, ${ }^{3}$ Laboratory Animal Research, and ${ }^{4}$ Biostatistics, Gülhane \\ Military Medical School; ${ }^{2}$ Department of Orthodontics, Etimesgut Military Hospital, all in Ankara
}

Submitted / Başvuru tarihi: 15.12.2008 Accepted / Kabul tarihi: 21.01.2009

\begin{abstract}
Objectives: The purpose of this study was to test the hypothesis that the hemostatic agent (FastAct) exerts favourable effect on wound healing and tissue repair alone and along with prilocaine hydrochloride in vivo. Wound healing process is a complex procedure that starts with bleeding and hemostasis. Comprising of bovine factor proteins II, VII, IX and X, FastAct is used as a catalyst in the clot formation process to activate factors II, V, VIII and XIII.
\end{abstract}

Materials and Methods: The study was performed on 21 Wistar male rats. Cutaneous incisions at the length of $4 \mathrm{~cm}$. were made on the dorsal side of all animals. In seven, FastAct was applied alone between the wound edges and, in the other seven, FastAct was applied along with prilocaine. The wounds were sutured by resorbable suture material.

Results: The specimens were obtained on the seventh day. Wound breaking strength test was performed before histological examination. In the FastAct group the epithelialization and the closure of the wound edge were better than the other groups. The results of the breaking strength test showed that the results were best in FastAct group.

Conclusion: It's concluded that FastAct accomplished hemostasis, facilitated wound healing in accordance with natural processes.

Key words: Wound healing; hemostatic agent; prilocaine hydrochloride.
Amaç: Bu çalışmanın amacı, in vivo olarak hemostatik bir ajanın (FastAct) prilokain hidroklorid ile beraber veya onsuz, yara ve doku iyileşmesini kolaylaştırdığı hipotezinin test edilmesidir. Yara iyileşmesi kanama ve hemostaz ile başlayan kompleks bir prosedürdür. Sığır protein faktörleri II, VII, IX ve $X$ 'u ihtiva eden FastAct pıhtı oluşumunda faktör II, V, VIII ve XIII'ü aktive etmesi için katalizör olarak kullanılır.

Gereçler ve Yöntemler: Çalışma 21 erkek Wistar rat üzerinde gerçekleştirildi. Tüm hayvanların sırtında $4 \mathrm{~cm}$ 'lik kutanöz insizyonlar yapıldı. Yedi hayvanda yara kenarları arasına sadece FastAct uygulanırken, diğer yedisinde FastAct prilokain ile birlikte uygulandı. Yara dudakları rezorbe olan sutur materyali ile kapatıldı.

Bulgular: Örnekler yedinci gün elde edildi. Histolojik inceleme öncesinde örneklere germe ve çekme testleri uygulandı. FastAct grubunda epitelizasyon ve yara iyileşmesinin diğer gruba göre daha iyi olduğu tespit edildi. Germe ve çekme testlerinde FastAct grubu sonuçlarının daha iyi olduğu gözlendi.

Sonuç: FastAct'in hemostazisi sağladığı, doğal süreçler yardımıyla yara iyileşmesini kolaylaştırdığı sonucuna ulaşıımıştır.

Anahtar sözcükler: Yara iyileşmesi; hemostatik ajan; prilokain hidroklorid. 
The use of local agents to achieve hemostasis is an old and complex subject in surgery. In the event of hemorrhage, hemostasis is naturally carried out by vasal contraction, platelet aggregation, activation of coagulation factors and blood flow. During an operation, sometimes, it is not possible to wait for the natural hemostatic process to occur, and therefore, additive methods to obtain a stable coagulum have to be used. In general, these methods can be classified into three basic categories: thermal, mechanical or chemical means. ${ }^{[1-3]}$

When a vessel or artery is damaged and starts bleeding, the body initiates a complex process aiming at stopping the bleeding by forming a clot. Clot formation begins with the release of tissue and platelet thromboplastin. This triggering mechanism causes a series of complex reactions known as the cascade phenomena. The clot formation process is a protein chain reaction that, as a cascade, produces thrombin in the blood. Thrombin activates fibrinogen and converts it to fibrin: sticky fibers together with platelets form platelet plugs, which, signifies the initiation of the clot. The active form of FastAct ${ }^{\circledR}$ is comprised of bovine factor proteins II, VII, IX and X, and does not alter the cascade phenomena system, but acts as a catalyst in the clotting process. FastAct $\AA$ activates factors II, V, VIII and XIII while supporting both the intrinsic and extrinsic systems and it is able to overcome anticoagulant drugs and factor deficiencies. ${ }^{[4-6]}$

In vivo, the wound healing process is a complex procedure that can be divided into distinct phases: the inflammatory phase, proliferative phase, and maturation phase. Within the inflammatory phase, hemostasis is followed by invasion of neutrophils and macrophages that help us to fight infection and remove debris. The macrophages also have chemoattractant properties that attract fibroblasts to the wound site. ${ }^{[6,7]}$

Disturbances can occur during wound healing repair in all of these phases, especially in the exudative phase, when changes of local or systemic origin compromise the quality and the quantity of fibrin initially formed. The necessity of the presence of adequate fibrin for connective tissue development and epithelial tissue formation is largely known.

Frequently, oral surgeons have to assist patients who are under anticoagulant medication, an important condition that has to be considered before any surgical procedure, even apparently simple ones such as tooth extractions. The interruption of the anticoagulant therapy has to be carefully inquired, as it can increase the risk of thromboembolism. On the other hand, if treatment with these anticoagulants is not suspended, prolonged bleeding may occur. This can usually be controlled by hemostatic drugs which may change the healing process. ${ }^{[8]}$

Local anesthetics are divided into two functional groups based on their chemical properties: amides and esters. The ester group includes the earlier anesthetics; procaine, cocaine, and novocaine. The more modern amide group includes lidocaine (or xylocaine), mepivacaine (or carbocaine), prilocaine (or citanest), bupivacaine (or marcaine), and etidocaine (or duranest). [9] Various local anesthetic agents are in use for dental practice. These substances have various effects on the healing of surgical wounds. Many studies aim at finding safer and more effective local anesthetic agents. Local anesthetics are known to have modest dose-related effects on wound healing. ${ }^{[10]}$ In this experimental study, the effect of FastAct ${ }^{\circledR}$ on the surgical wound healing was compared with FastAct ${ }^{\circledR}$ plus prilocaine hydrochloride.

\section{MATERIALS AND METHODS}

All animal experimentations were carried out with the approval of ethics committee of Gülhane Military Medical Academy.

\section{Study Design}

This study was designed as an open trial involving 21 healthy Wistar rats weighing between 200 and 250 gr. Twenty one animals composed three different groups and each group included seven animals. The first group was assigned as control group. In the second group FastAct ${ }^{\circledR}$ was applied alone and in the third group FastAct ${ }^{\circledR}$ was applied with prilocain hydrochloride. The animals were exposed to the same ambient temperature, nutrition, and day-night cycle to avoid physiological changes in hormones. Each of the study animals underwent the same surgical procedures on the first day of surgery. The hemostatic agent used in this study was FastAct ${ }^{\circledR}$ (Wortham Laboratories Inc. USA). For premedication, each animal was given xylazine hydrochlorur (alfazine) intramuscular $4 \mathrm{mg} / \mathrm{kg}$ body weight and all operations were carried out by using intramuscular injection of ketamine (alfamine) $(60 \mathrm{mg} / \mathrm{kg}$ body weight). The animals were maintained in a state of anesthesia during the surgery by intramuscular injection of $25 \mathrm{mg} / \mathrm{kg}$ ketamine when necessary.

\section{Dorsal Soft Tissue Incision Model}

To perform a standard type incision at the dorsal median line of all animals, a plastic ruler with scale was prepared for $4 \mathrm{~cm}$ length. With this material $4 \mathrm{~cm}$ fullthickness linear cutaneous wounds were created on the backs of twenty-one male Wistar rats. In 7 rats, $0.2 \mathrm{ml}$ of FastAct ${ }^{\circledR}$ was dropped on the wounds, in other group $0.2 \mathrm{ml}$ FastAct ${ }^{\circledR}$ was dropped with the injection of prilocaine hydrochloride $0.5 \mathrm{cc}$ each side of the wounds. All wounds were then closed by five simple 5-0 absorbable sutures, in identical places in all wounds (Fig. 1). Wound tissues were harvested 7 days later. On the seventh day, the specimens were excised at $1 \mathrm{~cm}$ width and length from the wound. At the same day, all specimens were first subjected to breaking strength test and then histological examination. 


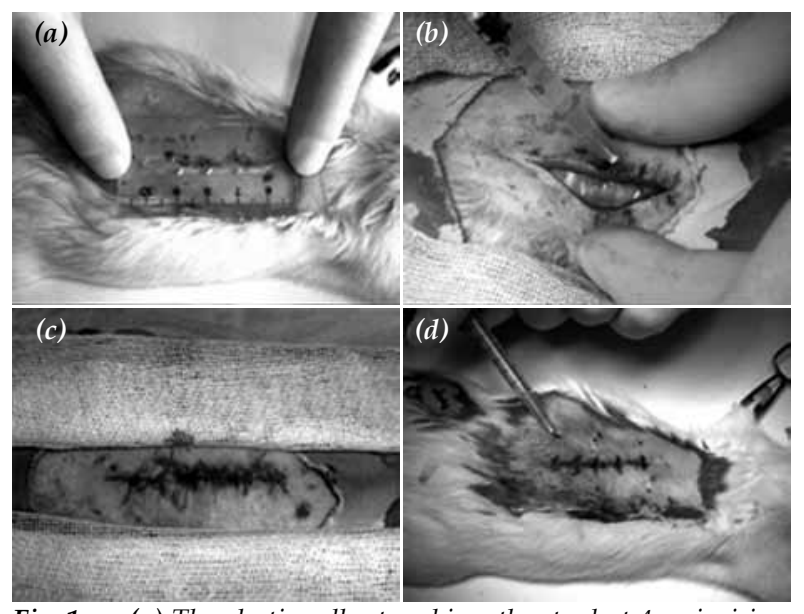

Fig. 1. (a) The plastic ruller to achieve the stardart $4 \mathrm{~cm}$ incision

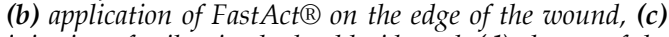
injection of prilocaine hydrochloride and, $(d)$ closure of the wound.

\section{Wound Breaking Strength Test}

In the Lloyd LRX (Lloyd LRX, Fareham Hants, England) system $10 \mathrm{~mm} / \mathrm{min}$ of pulling force was applied to all skin pieces of the rats (Fig. 2). The pulling force was applied in vertical direction to the incision line. At the time of breaking, the strength value was noted for breaking point and expressed as Newtons ( $1 \mathrm{~N}=101.97 \mathrm{~g})$.

\section{Histological analysis}

$10 \%$ formalin solution was used for the transfer and fixation of the tissue samples. The wound edges were reduced so that they can remain in the middle. The reduced samples were fixed in the $10 \%$ formalin solutions for 7 days. To block these samples, the paraffin method was carried out. Shandon Lipshaw rotary microtome was used to cross-section the samples at $7 \mu \mathrm{m}$ thickness. Then the sections were dyed with Masson's trichrome stain that dyed tissue structures. The sections were examined under a light microscope. Morphometry was performed in 21 samples by means of a microcomputer analysis system (MCID, Ontario, Canada). The

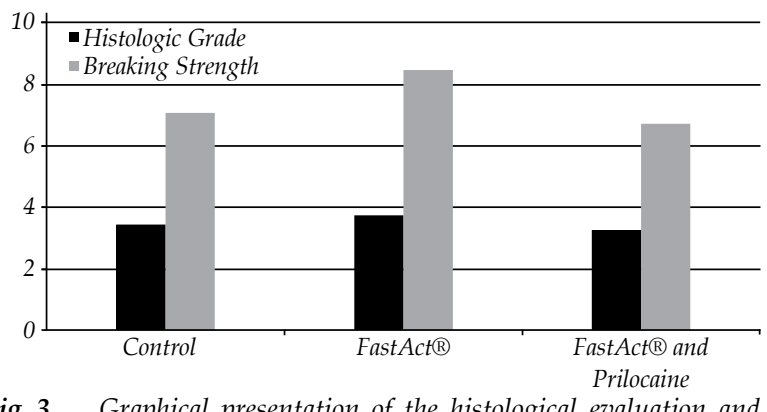

Fig. 3. Graphical presentation of the histological evaluation and breaking strength test of three groups.

quantification of the neoformed collagen fibers were detected in a randomly chosen $100 \times 75 \mu \mathrm{m}$ field for each sample. Four criteria ${ }^{[10]}$ shown below were used for examination of the samples:

Stage 1: Stage of inflammation. The most early stage of wound healing. There is edema in many blood vessels in the form of angioblasts and effective fibroblasts, abundant lymphocytes, and macrophages.

Stage 2: Development of the granulation tissue. Edema is reduced. Blood vessel formation is completed and abundant myofibroblasts are observed. The number of lymphocytes and macrophages are decreased. Collagenization starts.

Stage 3: Development of the scar tissue. Wound healing is characterized by increased fibroblast and collagen. Epithelialization starts at the edge of the wound.

Stage 4: Completion of the epithelialization. Wound edges come closer and epithelialization is completed.

\section{Statistical Analysis}

The SPSS 15.00 for Windows (SPSS Inc, Chicago, IL., USA) packet programs were used to analyze the collected data. The test of the convenience of normal distribution (Shapiro-Wilk) was applied to all groups and the results revealed that the data of histologic grade and breaking strength test were convenient to the normal
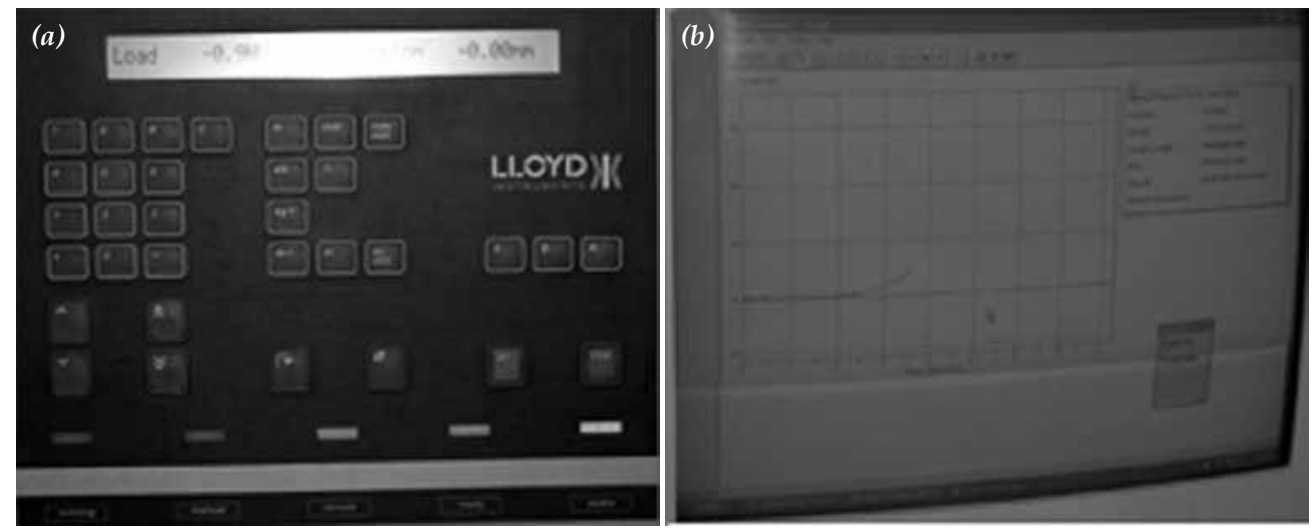

Fig. 2. (a) The control panel and, (b) the monitor of Lloyd LRX (Lloyd LRX, Fareham Hants, England) system. 
The Effect of a Hemostatic Agent (FastAct) to Wound and Tissue Repair in a Rat Model

Table 1. The results of the histologic evaluation and breaking strength test of ANOVA.

\begin{tabular}{|c|c|c|c|c|c|c|c|c|}
\hline \multirow[b]{2}{*}{ Parameters } & \multirow[b]{2}{*}{ Groups } & \multirow[b]{2}{*}{$\mathrm{n}$} & \multirow[b]{2}{*}{ Mean } & \multirow[b]{2}{*}{ Std. Dev. } & \multicolumn{2}{|c|}{$\begin{array}{l}\text { 95\% Confidence } \\
\text { Interval }\end{array}$} & \multirow[b]{2}{*}{$\mathrm{F}$} & \multirow[b]{2}{*}{$p^{*}$} \\
\hline & & & & & Lower & Upper & & \\
\hline \multirow{3}{*}{$\begin{array}{l}\text { Histologic } \\
\text { Grade }\end{array}$} & Control & 7 & 3.50 & 0.20 & 3.31 & 3.69 & \multirow{3}{*}{7.875} & \multirow{3}{*}{0.003} \\
\hline & FastAct $\AA$ & 7 & 3.75 & 0.20 & 3.56 & 3.94 & & \\
\hline & $\begin{array}{c}\text { FastAct }{ }^{\circledR} \text { and } \\
\text { Prilocaine }\end{array}$ & 7 & 3.25 & 0.29 & 2.98 & 3.52 & & \\
\hline & Control & 7 & 7.04 & 0.67 & 6.43 & 7.66 & \multirow{3}{*}{11.992} & \multirow{3}{*}{$<0.001$} \\
\hline Breaking & FastAct ${ }^{\circledR}$ & 7 & 8.46 & 0.64 & 7.87 & 9.05 & & \\
\hline Strength & $\begin{array}{l}\text { FastAct } ₫ \text { and } \\
\text { Prilocaine }\end{array}$ & 7 & 6.67 & 0.84 & 5.90 & 7.44 & & \\
\hline
\end{tabular}

* Test results of histologic evaluation and breaking-strength test showed that there were statistically significant differences between the groups.

distribution. Mean \pm standard deviation and $95 \%$ confidence interval values were used for definitive statistics. The control and FastAct ${ }^{\circledR}$ groups were compared statistically with the one way analysis of variance (ANOVA) and Bonferroni post-hoc tests. The $p$ value $\leq 0.05$ was accepted statistically significant.

\section{RESULTS}

At the end of seventh day, complete wound healing was observed in all subjects. The results of the histological examination and breaking strength test are presented in Table 1 and Fig. 3. In FastAct ${ }^{\circledR}$ group histologically the presence of the vascular granulation tissue was better than the control and FastAct@-prilocaine groups (Fig. 4a). Also, the epithelialization and the closure of the wound edge were better than the other groups. As shown in Table 1 the histological grade values were lower in FastAct ${ }^{\circledR}$-prilocaine group (Fig. 4b) than those in the control group and FastAct ${ }^{\circledR}$ group. The histologic evaluations between the experimental groups showed statistically significant difference $(\mathrm{F}=7.875 ; \mathrm{p}=0.003)$ (Table 1$)$. While the histologic evaluation difference of 0.50 grade between FastAct ${ }^{\circledR}$ and FastAct ${ }^{\circledR}$-prilocaine groups was statistically significant $(p=0.003)$, the difference between the other groups was not significant $(\mathrm{p}>0.05)$ (Table 2). Also statistically significant differences were found between experimental groups when the breaking strength test results were analyzed $(\mathrm{F}=11.992 ; \mathrm{p}<0.001)$ (Table 1). The difference of 1.41 Newton between the

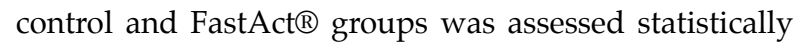
significant $(p=0.005)$. Similarly the difference of 1.79 Newton between FastAct $₫$ and FastAct $₫$-prilocaine groups was statistically significant $(\mathrm{p}=0.001)$. On the other hand the difference of 0.37 Newton between the control and FastAct ${ }^{\circledR}$-prilocaine groups was not statistically significant $(\mathrm{p}=1.000)$ (Table 2$)$.

\section{DISCUSSION}

Wound healing is the process of repair that follows injury to the skin and other soft tissues. Wounds may result from a trauma or a surgical incision. The healing capacity of a wound depends on the part of its depth, as well as on the overall health and nutritional status of the individual. ${ }^{[1]}$

Following injury, an inflammatory response occurs and the cells below the dermis (the deepest skin layer) begin to increase collagen (connective tissue) production. Later, the epithelial tissue (the outer skin layer) is regenerated. Dietary modifications and nutritional and herbal supplements may improve the quality of wound healing by influencing these reparative processes or by limiting the damaging effects of inflammation. ${ }^{[12]}$

Table 2. The post-hoc multiple comparisons results of histologic grade and breaking strength.

\begin{tabular}{|c|c|c|c|c|}
\hline Dependent Variable & (I) group & (J) group & Mean Difference (I-J) & $p^{*}$ \\
\hline \multirow[b]{2}{*}{ Histologic } & \multirow{2}{*}{ Control } & FastAct $\AA$ & -0.25 & 0.188 \\
\hline & & FastAct $®$ and Prilocaine & 0.25 & 0.188 \\
\hline Grade & FastAct ${ }^{\circledR}$ & FastAct ${ }^{\circledR}$ and Prilocaine & 0.50 & 0.003 \\
\hline \multirow{3}{*}{$\begin{array}{l}\text { Breaking } \\
\text { Strength }\end{array}$} & \multirow{2}{*}{ Control } & FastAct $®$ & -1.41 & 0.005 \\
\hline & & FastAct ${ }^{\circledR}$ and Prilocaine & 0.37 & 1.000 \\
\hline & FastAct ${ }^{\circledR}$ & FastAct $®$ and Prilocaine & 1.79 & 0.001 \\
\hline
\end{tabular}

* There were statistically significant differences; between the FastAct ${ }^{\circledR}$ and FastAct $®$-prilocaine groups in histologic evaluation. Similarly the differences; between control and FastAct ${ }^{\circledR}$, FastAct ${ }^{\circledR}$ and FastAct ${ }^{\circledR}$-prilocaine groups were significant in breaking-strength test. 

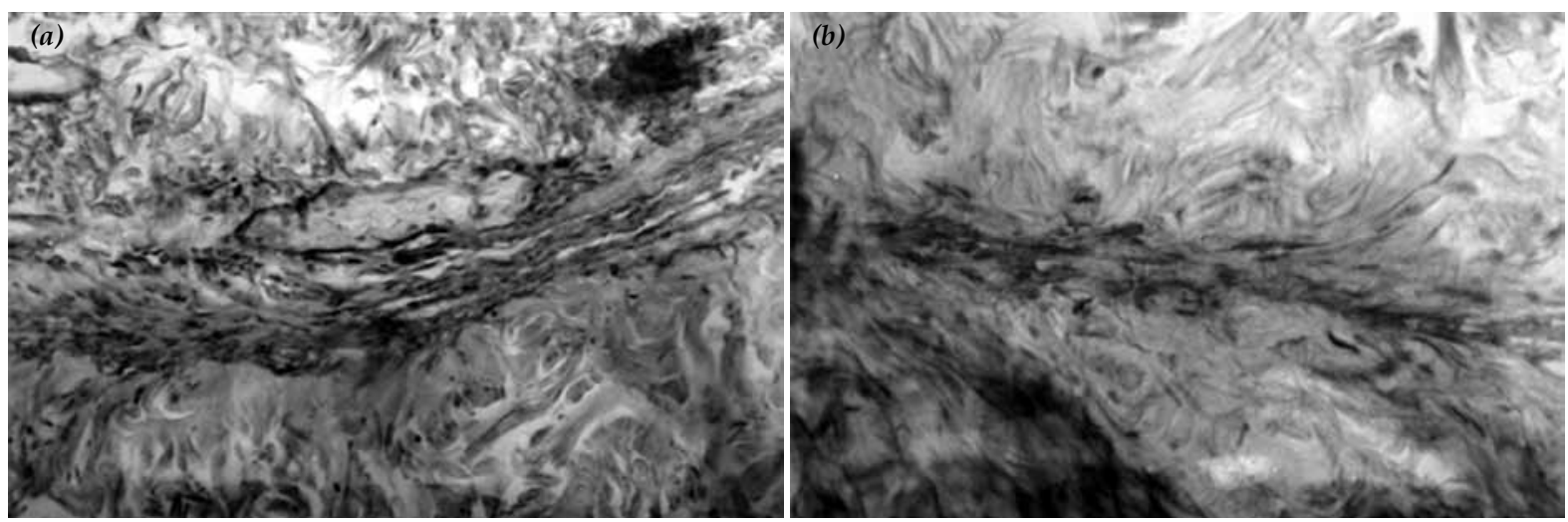

Fig. 4. Masson's trichrome stains of wound tissue at day 7. (a) Representative tissue from the FastAct $\mathbb{R}$ treated wound. Epithelialization

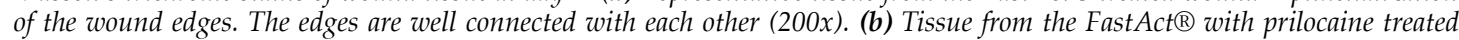
wound. Insufficient epithelial cell proliferation between the wound edges. It's observed that the blood vessel formation is not completed yet (200x).

Inflammation is the initial response to injury. The inflammatory response promotes the healing process and provides the milieu for the restoration of structural integrity. Tissue trauma and local bleeding result in activation of some factors, which in turn initiates various biochemical systems such as the clothing, complement, and kinin cascades, releasing mitogens and chemoattractants. ${ }^{[13]}$

FastAct ${ }^{\circledR}$ is comprised of hemostatic factors. It facilitates clot formation by supporting the cascade system and catalyzing the extrinsic and intrinsic pathways at the levels of Factor VII (extrinsic pathway) and Factor IX (intrinsic pathway) respectively, achieving a blood clot. ${ }^{[4]}$

The formation of the blood clot facilitates the closure of the wound, and supports the healing process. In this study, in the FastAct ${ }^{\circledR}$ group, histologically the presence of the vascular granulation tissue compared to the control and FastAct ${ }^{\circledR}$-prilocaine groups were observed. Also, the epithelialization and the closure of the wound edge were better than the other groups. In addition to histological superiority, the results of the breaking strength test values showed that for FastAct ${ }^{\circledR}$ was better in this respect as well. Statistically analysis results support these findings and showed the superiority of the use of FastAct ${ }^{\circledR}$ alone compared with other groups.

Some researchers have examined the effects of local anesthetic agents on the healing of the surgical wounds and they have stated that the local anesthetics delay the healing of wounds. ${ }^{[14-16]}$

Eroglu et al., ${ }^{[17]}$ evaluated the effects of lidocaine/ prilocaine cream on wound healing. They concluded that lidocaine/prilocaine cream as topical anesthetic agent had no adverse effect on an incisional wound model.

Smith et al., ${ }^{[18]}$ compared the effectiveness of prilocaine-phenylephrine (Prilophen), a new topical anesthetic that does not contain cocaine, with that of lidocaine infiltration during repair of lacerations on or near mucous membranes in children. They concluded that the per- formance of Prilophen was rated by two of the observer groups as statistically inferior to that of lidocaine infiltration; however, the differences in pain scores were small and may not be considered clinically significant.

Nykanen et al., ${ }^{[19]}$ compared a eutectic mixture of lidocaine and prilocaine (EMLA, Astra Pharmaceuticals, Inc) with $1 \%$ lidocaine infiltration to determine the effect on wound healing in a prospective single blind study using the rat model. They concluded that EMLA does not affect wound healing adversely and is comparable to $1 \%$ lidocaine infiltration in the animal model.

In our study, the histologic evaluation of the tissues revealed that in FastAct $\AA$-prilocaine group, the development of the vascular granulation tissue, fibrous granulation tissue, epithelial proliferation and the junction of the wound edge were less satisfactory than the others after 7 days. In addition, in the breaking strength test FastAct ${ }^{\circledR}$ group showed the highest rates compared with control and FastAct $\AA$-prilocaine groups. Statistically, there were significant differences between FastAct ${ }^{\circledR}$ groups and the others. At the end of this study, it was considered that the application of the FastAct ${ }^{\circledR}$ has facilitated the healing and closure of the wound.

In this study, it has been observed that both the histologic and breaking strength test results were best in FastAct ${ }^{\circledR}$ group. The average of the histologic grade and breaking strength test values of the FastAct $\AA$-prilocaine group was lower than those of the others, and it was concluded that prilocaine delayed the wound healing. In our opinion, in view of the results of this study, FastAct ${ }^{\circledR}$ can be regarded as a safe hemostatic agent that also facilitates the wound healing in accordance with the natural processes.

\section{REFERENCES}

1. Schonauer C, Tessitore E, Barbagallo G, Albanese V, Moraci A. The use of local agents: bone wax, gelatin, collagen, oxidized cellulose. Eur Spine J 2004;13 Suppl 1:S89-96.

2. Malmquist JP, Clemens SC, Oien HJ, Wilson SL. Hemostasis 
of oral surgery wounds with the HemCon Dental Dressing. J Oral Maxillofac Surg 2008;66:1177-83.

3. Soares LP, Oliveira MG, Pinheiro AL, Fronza BR, Maciel ME. Effects of laser therapy on experimental wound healing using oxidized regenerated cellulose hemostat. Photomed Laser Surg 2008;26:10-3.

4. FastAct product catalogue. Available from: http://www. toplibra.co.il/catalogMain.asp?cat_id=6\&id=24.

5. He Y, Chang G, Zhan S, Song X, Wang X, Luo Y. Soluble tissue factor has unique angiogenic activities that selectively promote migration and differentiation but not proliferation of endothelial cells. Biochem Biophys Res Commun 2008;370:489-94.

6. Kroez M, Lang W, Dickneite G. Wound healing and degradation of the fibrin sealant Beriplast $\mathrm{P}$ following partial liver resection in rabbits. Wound Repair Regen 2005;13:31823.

7. Pietramaggiori G, Yang HJ, Scherer SS, Kaipainen A, Chan RK, Alperovich M, et al. Effects of poly-N-acetyl glucosamine (pGlcNAc) patch on wound healing in $\mathrm{db} / \mathrm{db}$ mouse. J Trauma 2008;64:803-8.

8. Padovan LE, Okamoto T, Rezende MC, Curvêllo VP, Nicolielo D, Matsumoto MA. Fibrin adhesive implant in wound healing repair of dental sockets with topical application of epsilon aminocaproic acid: histological analysis. J Biomed Mater Res B Appl Biomater 2005;73:209-13.

9. Dinehart SM. Topical, local, and regional anesthesia. In: Wheeland RG, editor. Cutaneous surgery. 1st ed. Philadelphia: WB Saunders; 1994. p. 102-12.
10. Doğan N, Uçok C, Korkmaz C, Uçok O, Karasu HA. The effects of articaine hydrochloride on wound healing: an experimental study. J Oral Maxillofac Surg 2003;61:1467-70.

11. Morin RJ, Tomaselli NL. Interactive dressings and topical agents. Clin Plast Surg 2007;34:643-58.

12. Wound Healing. Available from: http://www.vitacost. com/Healthnotes/Concern/Wound-Healing.aspx

13. Shetty V, Bertolami C. The physiology of wound healing. In: Peterson LJ, editor. Principles of oral and maxillofacial surgery. 3rd ed. Philadelphia: Lippincott; 1992. p. 3-18.

14. Morris T, Tracey J. Lignocaine: its effects on wound healing. Br J Surg 1977;64:902-3.

15. Eriksson AS, Sinclair R, Cassuto J, Thomsen P. Influence of lidocaine on leukocyte function in the surgical wound. Anesthesiology 1992;77:74-8.

16. Drucker M, Cardenas E, Arizti P, Valenzuela A, Gamboa A. Experimental studies on the effect of lidocaine on wound healing. World J Surg 1998;22:394-7.

17. Eroglu E, Eroglu F, Agalar F, Altuntas I, Sutcu R, Ozbasar D. The effect of lidocaine/ prilocaine cream on an experimental wound healing model. Eur J Emerg Med 2001;8:199-201.

18. Smith GA, Strausbaugh SD, Harbeck-Weber C, Cohen DM, Shields BJ, Powers JD. Prilocaine-phenylephrine topical anesthesia for repair of mucous membrane lacerations. Pediatr Emerg Care 1998;14:324-8.

19. Nykanen D, Kissoon N, Rieder M, Armstrong R. Comparison of a topical mixture of lidocaine and prilocaine (EMLA) versus 1\% lidocaine infiltration on wound healing. Pediatr Emerg Care 1991;7:15-7. 